Section Editor Mitchell S.V. Elkind, MD, MS

Liuna Jang, MD

François-Xavier Borruat, MD

Correspondence to

Dr. Borruat:

francois.borruat@fa2.ch
Supplemental data at www.neurology.org

\section{Teaching Video NeuroImages: Micronystagmus of oculopalatal tremor}

回両
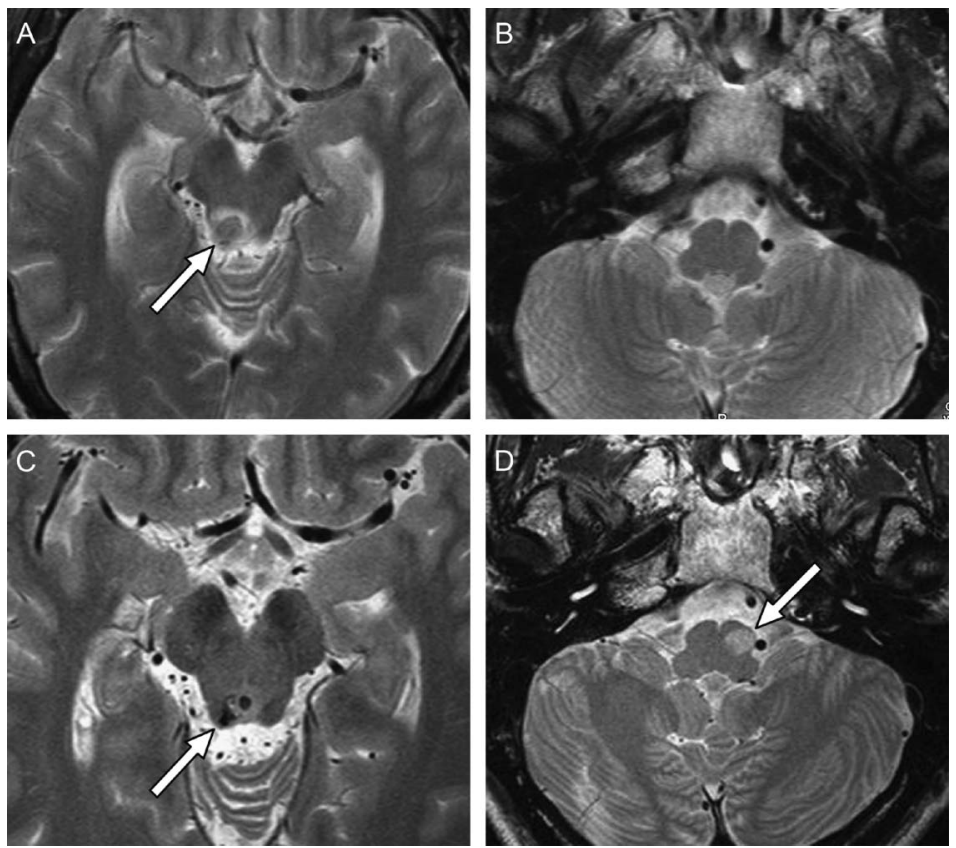

Initially: right inferior colliculus hemorrhage (A, arrow) and normal inferior olivary nucleus (B). Three months later: resolution of hemorrhage $(C$, arrow) and left inferior olivary nucleus hyperintense signal ( $D$, arrow).

Three months after brainstem hemorrhage, MRI revealed a hyperintense lesion of the left inferior olivary nucleus of a 45-year-old man (figure). The patient was completely asymptomatic, but exhibited oculopalatal tremor (OPT), rhythmic palatal oscillations, and small-amplitude vertical pendular nystagmus of the right eye, best visualized on fundus examination (see video).

OPT is caused by interruption of the inhibitory dentato-olivary pathway, resulting in synchronous oscillations of the olivary neurons. This pathway crosses the midbrain then descends to the contralateral inferior olivary nucleus. ${ }^{1,2}$

Asymptomatic OPT is rare. Micronystagmus can be overlooked with simple observation but is readily detected during fundus examination.

\section{AUTHOR CONTRIBUTIONS}

Liuna Jang is an author, and contributed to drafting and revising the manuscript. François-Xavier Borruat is an author, and contributed to data acquisition and revising the manuscript.

\section{DISCLOSURE}

L. Jang reports no disclosures. F.-X. Borruat received honoraria from Novartis for participating in clinical trials and from Allergan for speaking engagements. Go to Neurology.org for full disclosures.

\section{REFERENCES}

1. Kim JS, Moon SY, Choi KD, Kim JH, Sharpe JA. Patterns of ocular oscillation in oculopalatal tremor: imaging correlations. Neurology 2007;68:1128-1135.

2. Shaikh AG, Hong S, Liao K, et al. Oculopalatal tremor explained by a model of inferior olivary hypertrophy and cerebellar plasticity. Brain 2010;133:923-940.

From the Hôpital Ophtalmique Jules-Gonin, University Ophthalmology Department, University of Lausanne, Switzerland.

This study was approved by the Swiss Federal Department of Health (authorization \# 035.0003-48). 


\section{Neurology}

\section{Teaching Video NeuroImages: Micronystagmus of oculopalatal tremor Liuna Jang and François-Xavier Borruat Neurology 2013;80;e27 \\ DOI 10.1212/WNL.0b013e31827debc3}

This information is current as of January 14, 2013

\section{Updated Information \& Services \\ Supplementary Material \\ References \\ Subspecialty Collections}

Permissions \& Licensing

Reprints including high resolution figures, can be found at: http://n.neurology.org/content/80/3/e27.full

Supplementary material can be found at: http://n.neurology.org/content/suppl/2013/01/12/80.3.e27.DC1

This article cites 2 articles, 1 of which you can access for free at: http://n.neurology.org/content/80/3/e27.full\#ref-list-1

This article, along with others on similar topics, appears in the following collection(s):

Clinical neurology examination

http://n.neurology.org/cgi/collection/clinical_neurology_examination Intracerebral hemorrhage

http://n.neurology.org/cgi/collection/intracerebral_hemorrhage

MRI

http://n.neurology.org/cgi/collection/mri

Nystagmus

http://n.neurology.org/cgi/collection/nystagmus

Information about reproducing this article in parts (figures,tables) or in its entirety can be found online at:

http://www.neurology.org/about/about_the_journal\#permissions

Information about ordering reprints can be found online:

http://n.neurology.org/subscribers/advertise

Neurology ${ }^{\circledR}$ is the official journal of the American Academy of Neurology. Published continuously since 1951, it is now a weekly with 48 issues per year. Copyright (O) 2013 American Academy of Neurology. All rights reserved. Print ISSN: 0028-3878. Online ISSN: 1526-632X.

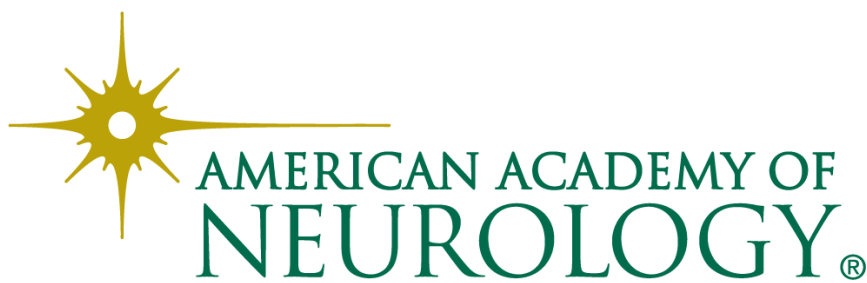

